\title{
The Position of the UN Conventions to Determine and Guarantee Human Rights
}

\author{
Bahman Akbari ${ }^{1}$ \\ ${ }^{1}$ Rasht, Iran \\ Correspondence: Bahman Akbari, Rasht, Iran. E-mail: bahman.akbari1@yahoo.com
}

Received: June 22, 2016

doi:10.5539/jpl.v10n3p38
Online Published: June 1, 2017

URL: https://doi.org/10.5539/jpl.v10n3p38

\begin{abstract}
In the present era, providing human rights represents the governance quality of a government and human rights treaties are criteria for its assessment. Also the UN human rights conventions, because of their international nature in the past seven decades, have been the main representative to reflect man's fundamental demands. Now the main question is that to what extent these conventions are remarkable and effective in order to explain and guarantee human rights in the international arena? The author believes that the conventions are the most important international mechanisms to identify human rights which compared to the past history of mankind have offered the most comprehensive international regulations in order to reflect the fundamental human rights. But then, two main factors undermined the effectiveness of the conventions. The first factor is intratextual drawbacks of the conventions which are divided into three drawbacks: reservation, withdrawal and arbitrary essence of accepting the committees' competence. The second and more important factor is the reasons out of the conventions which are divided into two categories: the doctrine of privity of contract and disobedience by some governments under the ideological or moral reasons. The first factor can be addressed by the secondary amendments. However, the big challenge is the second factor which mechanism to settle it are to inform the international community about the importance of the UN human rights conventions, creating intersubjective understanding and eventually accepting the supremacy of international human rights over internal law.
\end{abstract}

Keywords: conventions, critics, human rights, peremptory norms

\section{Introduction}

Today, one of the most important criteria for evaluating good governance, without doubt, is the rule of human rights and its realization is a component of human society's prosperity. Development of democracy, understanding human dignity and the elimination of structures based on discrimination and oppression are indebted to humanitarian thoughts and movements which have caused realization and guarantee of human rights to be the concomitant of human societies life and a requisite for legitimacy of governments.

In this regard, UN human rights conventions (UNHRC) should be known as the center of all human rights approaches at the present time due to the significance of the 'United Nations' in the contemporary international system. Hence, rule of mentioned conventions should be considered as an assessment criteria for the rule of human rights in the world today.

In the past few decades, the major contribution of international law studies dedicated to the field of human rights, but we hardly have seen precise and comprehensive analysis providing various reasons for continuing human rights violations.

In this article the fundamental reasons for the continued human rights violations will be examined by putting the UNHRC in the focus of attention and as the most pervasive human rights instruments of the contemporary era.

This article is seeking to answer this question that to what extent are the UNHRC important and effective in order to explain and guarantee human rights in the international arena?

In author's belief, taking into account the importance of international treaties in the creation of contemporary international order, the UNHRC, in the first step, are the most important international mechanism to explain and identify human rights, but on the rest of the way two major reasons cause better fulfillment and guarantee of the rights are not acquired in some countries of the world. 
The discussion continues in the following three parts.

\section{The Role of International Treaties in the Contemporary International System}

The purpose of international law is to establish an international equal order through which human society achieves sustainable peace, comprehensive development, freedom, security and ever increasing excellence in the shadow of the interdependence. In order to fulfill this important issue the most important mechanism of international law is to conclude international treaties. "The making of international laws through treaty making thus is the most desired "mode of generating international laws" (Sangroula, 2010, p.4) Treaty accounts for common aims, makes the parties closer to each other and aligned and aligns them on track to fulfill their needs. In a sentence, treaties bind the destiny of nations together and in such circumstances, the profit of one side is other side's profit and loss of each one is other's loss.

"Treaties are older than the idea of international law." (Allott, 1999, p.42)Reviewing the formation of international treaties, the oldest sign found is a text in the 'Sumerian' language dates back to $2100 \mathrm{BC}$ which was concluded between two territories, 'Lagash' and 'Umma', in Mesopotamia. Historical experience of all human societies from then to now has verified the importance of treaties in the coexistence of nations. In the last century by forming 'League of Nations' Article 18 of covenant caused several changes in the law of treaties including codification of signing procedure, registration and publication of treaties. But the culmination of the law of treaties evolution was establishing the UN. "One of the most striking trends in international relations since World War II has been the proliferation of treaties."(Miles \&Posner, 2008, p.2) Thus, since 1950, the 'International Law Commission' (ILC) started to regulate the law of treaties by recommendation of the UN 'General Assembly'. After several years, 'Vienna Convention on the law of treaties' (VCLT) was adopted on 22 May 1969 and ultimately entered into force on 27 January 1980. This treaty is, indeed, a framework to create an international agreement.

"A standard prediction is that states enter into treaties to secure gains from cooperation... The advantage of the treaty is that it allows governments to produce different public goods at different scales."(Miles and Posner, ibid., p.4) Besides the significance of common interest arising from treaties, today international treaties, as the most important source of international law, reduce the power of governments and increase executive power of international law so that through this path realize high ultimate ideals of international law. Just as the international treaty law is "a meeting point of the necessity to take international obligations (some kind of limitation on exercise of sovereignty and protection of sovereignty)."(Sangroula, ibid., p.2)Today, with the proliferation of treaties associated with the fundamental issues of the international community, international treaties must be known as the most important mechanism for achieving consensus and collective security of nations. If the realization of the international community's ideals needs synergies of nations, consensus of nations also entails the further rule of international law and this is, in turn, contingent upon understanding the significance of international treaties.

\section{International Treaties and Its Position on Explaining Human Rights}

Although the first international human rights document dates back to $539 \mathrm{BC}$ that was announced in the form of an inscription by the decree of 'Cyrus the Great' in the time of conquering 'Babylon' (Note 1), but prior to the modern era contracts were still not perfect embodiment of individual rights versus might of the governments as a result of teleological thoughts of philosophers such as Plato, Aristotle, Cicero, Augustine, Aquinas and etc. Even up to the $19^{\text {th }}$ century the traditional definition of international law only governed the relations between the governments and the concept of 'Humanitarian law' in the form of 'Geneva Conventions' merely reflected the rights of people involved in war. However, throughout this period we witnessed emergence of treaties around the world, more or less, seeking to explain the basic rights of human beings. (Note2) In 1920 and during the establishment of the League of Nations, although the "notion that human rights should be internationally protected had not yet gained acceptance by the community of nations" (Buergenthal, Shelton \& Stewart, 2009, p.8) however, Art. 22 and 23 of the covenant was somehow reflection of concern for human rights. Art. 22 was about the mandate system to create an appropriate atmosphere for people who live in countries liberated from colonial rule and Art. 23 referred to fair working conditions, the administration of justice and attracting the attention of member states to international agreements, freedom of communication and general diseases control. But international law "since 1945 has focused primarily upon the protection of individual human rights".(Show,2008, p. 281)From this time onwards the emergence of liberal thought, which is considered the philosophical support for formation of $\mathrm{UN}$, heralded the advent of more and more human rights treaties. It is natural that the nations tired of war and weary of despotism of rulers this time with a more civilized thinking regulated a Charter whose rules and organizations emanating from it had to be the most thorough and expressive 
documents to reflect their legitimate demands. "This international community was premised on "faith in fundamental human rights': equality, the rule of law, social progress and cooperation between nations."(Steinerte \& Wallace, 2009, p. 10) Also this was the first time that the international community could explain and chase individuals rights enjoying mechanisms originated from international treaties beyond borders and free from absolute power of the governments. The human rights are so important in the UN structure that is stated in the very introduction of UN Charter and in fact "the UN Charter acknowledged human rights and their realization and protection as being of international concern."(Steinerte \& Wallace, ibid., p.11) Thus, the aim of formation of the UN and philosophical background of its relevant organs led to the conclusion of several human rights conventions in the rest of the way. The treaties which signed by representatives of nations to identify broad areas of fundamental human rights. The contracts that are no longer mere contract but certain principles ruling the governance of states and are among the axioms concerning the human life of citizens. "In assuming an obligation under a human rights treaty, a state usually assumes an obligation not only to other state parties and their citizens but also (indeed, often most centrally) to the state's own citizens."(Hathaway, 2007, p.591)

So it lasted a long time until humankind succeeded to vindicate their fundamental rights against totalitarianism of governments and a bound slave become a respectable man and the concept of human rights being explained in terms of contracts and treaties to be the governments duty's documents. Today, international treaties are the most important factors of regulating relations of states and general international treaties placed at the head of all the treaties and generally, all treaties concluded on human rights as the importance of subjects and purpose, are considered as general international treaties and rules derived from them as part of international peremptory rules.

Acknowledging the importance of the conventions in the contemporary international system, but desired goals of these treaties have not been achieved yet favorably and we still witness many forms of violation of the UNHRC in some parts of the world.(Note 3)Why after more than five centuries of humanitarian efforts and seven decades of formation of the UN and ratification of the charter of human rights and after some decades of ratification of other human rights treaties, human society is still faced with human rights violations in some parts of the world is the question its answer has several reasons, each of which plays an important role in undermining the effectiveness of the conventions and non-realization of their objectives. These reasons will be discussed later in this article.

\section{Factors Undermining the Effectiveness of UN Human Rights Conventions}

In explaining the reasons for failure to achieve aims of UNHRC perfectly, in author's belief, the reasons must be divided into two parts, i.e. internal and external. The internal reasons are the reasons caused by conventions themselves and external reasons refer to an incorrect legal presupposition and ideological approaches of critics.(Note4)Each of them will be discussed separately in the rest of the article.

\subsection{Reasons Caused by Conventions Themselves}

In this section we discuss the problems arising from the UNHRC, each of which plays a significant role in undermining the conventions ' effectiveness.

\subsubsection{Reservation}

Art.19 to 23 the VCLT addressed the issue of reservation and deduced from mentioned articles applying the reservation is also permitted in the case of silence of treaty. Accordingly, the majority of UNHRC expressly permit the exercise of the reservation (Note5) and silence of 'International Covenant on Civil and Political Rights' [ICCPR](1966) is a license for applying it. "This leaves many, if not most, important issues unresolved."'Swaine, 2006, p.308)Although these conventions considered reservations incompatible with the purpose and object of the conventions unacceptable, reservations enforced in some conventions could be considered, sort of, at odds with the objectives of the conventions that, in turn, may be a reason for the lack of effectiveness of filtering mechanism for incompatible reservations. The 'Convention on the Elimination of All Forms of Discrimination against Women' [CEDAW] (1979) (Note6) accepted reservations, as a result of which more than 50 states have joined the convention by applying reservation, among them some countries, predominantly Muslim, reservations were general.(Note 7)More than 50 states joined the 'Convention on the Rights of the Child' [CRC](1989) (Note 8) declaring the reservation, as well and we have been facing, in some cases, with vague and general reservations that are inconsistent with the raison d'etre of these conventions. (Note9)

'The International Court of Justice' (ICJ) in one of its advisory opinions considered the balance between the interests of the states and the objectives of the convention.(Note 10)"The Court indicated that reservations should not be contrary to the object and purpose of the treaty but did not propose any particular way of avoiding 
impermissible reservations."(Ziemele \& Liede, 2013, p.1137)In this regard, the 'Guide to Practice on Reservations to Treaties' says: to "assess the compatibility of a reservation with the object and purpose of a treaty containing numerous interdependent rights and obligations, account shall be taken of that interdependence as well as the importance that the provision to which the reservation relates has within the general tenour of the treaty, and the extent of the impact that the reservation has on the treaty."(UN, 2011, p.18)But it does not seem that descriptions of this kind can provide highly effective mechanisms to detect and deter incompatible reservations with the objectives of human rights conventions, because these conventions are essentially in the different area from other treaties. 'Human Rights Committee' in one of its opinions concerning the nature of human rights treaties notes: "such treaties, and the Covenant specifically, are not a web of inter-state exchanges of mutual obligations. They concern the endowment of individuals with rights. The principle of inter-state reciprocity has no place." (Human Rights Committee [HRC] ,1994).Thus, the committee "having taken an aggressive stance against reservations to human rights treaties."(Swaine, ibid, p.309)

Advantages and disadvantages have always been enumerated in relation to reservations. One of the main reasons for agreeing to the reservation is quantitative increase in parties to a treaty. But what use is the increase the members of a treaty by applying reservation and on the other hand, some governments with double standard behaviors in many cases relying on their reservation shirk their responsibilities arising from a convention despite the ratification of the convention? What use when a number of states approve the said conventions for their political prestige in the international arena but falter the importance of a convention with imposing numerous, general and vague reservations? "It should be noted that broadly speaking there has been for some time some unease in that reservations to human rights treaties might undermine the universality of human rights. Indeed, the Human Rights Committee's characterization of the International Covenant on Civil and Political Rights might lead one to think that VCLT cannot provide solutions to reservations problems in relation to human rights treaties".(Ziemele \& Liede, ibid., p.1136)The author's belief is also that there is no effective strategy in this area and merely stipulating a ban on the implementation of the reservation in the mentioned conventions can reserve the position and the fundamental purpose of these treaties. The author believes that since human right conventions are a reflection of international imperative rules, applying reservation is naturally in conflict with the objectives of the aforementioned conventions and of the major reasons for undermining the effectiveness and lack of proper realization of the objectives of the conventions.

\subsubsection{Withdrawal}

Withdrawal conditions have been announced in Art. 54 VCLT in 2 cases: one stipulated in the treaty itself and the other one in the case of the consent of all the parties. A number of UNHRC grant right of withdrawal to the parties in order to implement this right.(Note 11) But remarkable point is that "the evolution of international human rights law since the VCLT means that its pertinent provisions should now be read in light of the peremptory nature of human rights law.”(Naldi \& Magliveras, 2013, p.125)

Another issue is that in the implementation of the right of withdrawal only requirement is that it must elapse one year from presenting notification to the 'Secretary-General'. Much surprise! As if regulators of discussed conventions have forgotten they are regulating a treaty whose contents are actually a reflection of the fundamental rights of individuals at the international community. Indeed, human rights conventions have been dealt with as if they are trade pacts and contractual treaties. Besides, an "old adage says that no one likes to talk about divorce before a wedding."(Helfer, 2012, p.634)As the "UN Charter does not contain an exit clause. It appears that this was a deliberate ploy to emphasize the UN's objective of perpetuity and universality. Moreover, it reflected a conscious decision to avoid one of the pitfalls of the League of Nations, which explicitly provided for cessation of membership."(Naldi \& Magliveras, ibid., p.121)

The other matter is that some conventions have explicitly stated reservation prohibition, but none of them have applied such a prohibition on exit them. "If clauses prohibiting reservations are incorporated, there seems to be no good reason why explicit non-denunciation clauses could not be included."(Naldi \& Magliveras, ibid., p.126)However, the insertion of such a prohibition could have been an emphasis on the importance of UNHRC.

Art. 60 Para(5)VCLT expressing exceptions of the rule 'Termination or Suspension of the Operation of A Treaty as A Consequence of Its Breach', which is considered as an international customary rule, has excluded human rights treaties in resorting to this rule. That is a party to the treaty can terminate it on the grounds that the other side violated the provisions of the treaty, except in human rights treaties which resort to this rule is not allowed. So, how has the VCLT emphasized the significance of human rights conventions with such exception but withdrawal has been predicted in these conventions? "In the late 1990s... three Caribbean States denounced human rights treaties and withdrew from the jurisdiction of international human rights bodies in response to 
treaty interpretations that resulted in the de facto abolition of the death penalty in those countries... These and other examples illustrate how States use unilateral exit to disengage from or radically reconfigure existing forms of international cooperation."(Helfer, ibid., p.645) Has the important position of UNHRC not been shaken in advance even by their regulators themselves predicting such a right without the slightest obstacle and only after a period of 12 months? If international law believes that the provisions of international human rights conventions refer to the most basic human rights of individuals and its regulations are considered of imperative rules of international community, why any state could leave these conventions at any time according to the stipulated articles in these conventions? "Denunciation of a human rights treaty...is not a step to be taken lightly, as it is certain to attract deserved hostile criticism. It might at the very least constitute "a political disaster." That States should openly flirt with repudiation of their human rights obligations, particularly for short-term domestic political gain, is highly regrettable."(Naldi \& Magliveras, ibid., p.127)

\subsubsection{The Arbitrary Essence of Accepting Committees' Competence}

Although the desired objective of international law is governing its regulations in the international community more and more, the absence of effective sanctions has always known as one of the gaps in international law. In addition, nowhere "is the challenge of creating effective international law more daunting than in the area of human rights."(Hathaway, p.1)Therefore, the realization of an effective system of sanction to prosecute violators of international law, especially in the field of human rights, must be the main concern in the scope of studies and activities of international law. Of the ways to achieve this goal is increasing more and more parties of treaties on condition of accepting competence of the prosecutor institutions predicted in the treaties themselves. But a number of UNHRC, in a reverse action, expressly assign the acceptance of committees' competence which predicted in conventions to the governments' disposal.(Note 12)And that's one of the reasons to say: in "practice...the UN's human rights instruments have not been as effective at achieving their goals as hoped. ...the current $\mathrm{UN}$ human rights regime is extensive but the $\mathrm{UN}$ is often unable to respond to violations of that regime."(Hathaway, p.2)

When a government accepted and approved a treaty's object and purpose by signing it, why should not accept the authority of an institution that has been established to resolve disputes on the same subject? Aforementioned conventions explicitness in considering the acceptance of committees' competence optional is itself a factor in tarnishing the UNHRC and constant absence of effective sanctions in international law.

\subsection{Reasons out of the Conventions}

In examining the causes of the lack of proper realization of the ideal of UNHRC after analyzing the reasons arising from conventions themselves, other reasons (reasons beyond conventions) divided in two parts. One is the debate over scope and place of applying the 'privity of contract' and the level of non-party states' responsibilities and the other is disobedience to the UNHRC by critics. These two reasons put together and proposed in a single season, because, about human rights regulations, both reasons often caused by a same ideological-political origin. We will follow this discussion in two seasons.

\subsubsection{The Privity of Contract and Non-Party States}

According to a customary rule, treaties are binding only on the parties and its consequences are applicable only to the parties. In other words, by the conclusion of a treaty cannot confer rights or impose obligations arising under it on any third states without their consent. This rule which is emphasized in Art.34 VCLT is based on the 'Voluntarism' doctrine according to which independence and contractual nature of treaties means that a treaty cannot give rise to right or obligation on third states. Hence it is said for "states non-parties to the treaty, the treaty is res inter alios acta."'(Fitzmaurice, 2002, p.38)

Although the privity of contract rule is logical in the various types of contracts and is not disputable, it seems challenging as mentioned principle to be generalized to all provisions arising from the context of the actions of international law. In this case, international treaties that are the major sources of international law are all in parallel and mechanisms of international law will find purely conventional form. However, the author believes the effect of the privity of contract should be distinguished in three areas of treaties as follows:

First area, the realm of treaties which have purely contractual nature like various types of documents of partnership between states in various areas such as trade, extradition, etc. In this area the privity of contract is entirely dominated and "for third states treaties are something devoid of any legal consequence: they are a thing made by other". (Sangroula , ibid., p.2)

The second area is realm of treaties which have contractual nature, but international moral and logic require that parties be added to such treaties and non-accession of countries is an evasion, however legitimate, of an 
international obligation. Among these treaties the TRIPS can be named. The privity of contract is dominated in this area, as well and at least to date, the mechanisms of international law do not offer measures beyond this.

But the third area is the scope of treaties that contractual nature cannot be considered for them and international call for approval of such treaties is a type of public informing regarding the identification of norms whose imperativeness arose from the simple logic of the human. Hence, in author's belief the privity of contract do not prevail in this category of treaties. Indeed, "where treaties reflect customary law then non-parties are bound, not because it is a treaty provision but because it reaffirms a rule or rules of customary international law"(Show, ibid., p.95) And human rights conventions are categorized right in this category. If we recognize the privity of contract generalizable to this category of treaties, the most fundamental international rules will be easily exposed to instability and violence.

Therefore, the author believes the lack of transmission of the works of many general rules of international law, including provisions contained in human rights conventions to the non-party states is, however, a reality but a perpetuated mistake and in author's view, it is inadmissible. To support the view the following reasons are propounded:

First: the privity of contract has exceptions, including 'consequences of law-making or general treaties' that Art. 38 VCLT implies. In author's belief when the object of a treaty is on fundamental issues such as 'torture elimination' and a large number of states ratified the convention, other non-member states cannot violate the object matter of the convention since a norm came into existence by the international treaty. In other words, at least, the core issue of human rights conventions is capable to generalize to third states, because these conventions are basically in a different place and the major difference between this category of conventions and other treaties is that each of these conventions are essentially trying to create an international peremptory norm and a "peremptory, or jus cogens, norm is one that is understood by the international community as not permitting derogation." (Brilmayer \& Tesfalidet , 2011, p. 21)

Second: passing seven decades of UN establishment and membership of almost all the states in the organization, many norms derived from international law have been allowed to dominate over domestic law. The legitimacy of this process derived from the UN Charter that "it is normative with regard to its provisions on aims and principles."(Schrijver, 2006, p.5) In other words, states have been approved and accepted the UN Charter with membership in the organization and all legislation approved within the framework of principal and subsidiary UN organs are in fact an expression of the goals contained in the UN Charter. This relationship is particularly true in the case of the UNHRC provisions.

"As a consequence of the traditionally bilateral nature of international law, the law of international responsibility struggles to accommodate the reality of two or more potential wrongdoers."(Fink, 2016, p.16)In this regard, the willingness of international law, for example, in Art. 41 and 48 of the 'Draft Articles on Responsibility of States for Internationally Wrongful Acts' (2001)(Note 13) is toward creating an obligation or right to third states (non-injured party) to prevent violation of peremptory norms. "The ILC's Draft Articles on State Responsibility represent a combination of codification and progressive development in the area of third state responsibility for serious breaches of peremptory norms and obligations to the international community as a whole."(Bird, 2011, p.899)Therefore, why should human rights obligations and comply with its requirements not be generalizable to non-party states. Just as "human rights bodies have recognised positive obligations of state parties to prevent human rights violations committed by others."(Fink, ibid., p.7)

According to all of the cases mentioned in this section, the lack of absolute transferring of the UNHRC provisions to non-party states has been one of the reasons undermining the effectiveness of the conventions as a result of incorrect understanding of the nature and status of these treaties in the structure of contemporary international community. In addition, the author believes it is better the meaning of 'states parties' in the context of UNHRC inferred as UN member states, not necessarily the signatory states.

\subsubsection{Disobedience by Critics}

Although anti-humanitarian attitudes or anti-human rights policies are likely to be seen in all countries territory, more or less, since the subject of this paper is the UNHRC, naturally, the author's focus in this part of the article will be on those group of countries approach that vilify the nature of the conventions. In investigating the reasons for disobedience to the human rights conventions two views generally are cited by some governments.

From one perspective, the concepts of human rights exploited for political intentions, which causes critics reject the claim of liberal human rights and be placed in opposition position. According to these, contradictory approach of some Western states creates uncertainty in functional philosophy of human rights concepts and this 
question propounded by them that "why when civil rights and aliens rights in their lands [i.e. western countries] are talked about, various notes and interpretations are produced and disseminated by western governments to evade respect these rights, but enforcement and respect for these rights for other governments is always considered mandatory so that they [western countries] allow themselves to operate national and international capacity against the governments to guarantee these rights and consider any political and economic pressure as well as direct and indirect military threat their right?!" (Kadkhodaei \& Saed, 2011, p 56). In fact, this critical view based on oppositional behavior by governments rejects the basis of international human rights law. Regardless of how far this critical perspective is able to prove this contradictory behavior (allegedly) two points can be expressed in response to this critique. First, the contradictory behavior or breach of provisions of a convention by one or more member states is apart from being good or bad, right or wrong and favorable or unfavorable of provisions of the convention. In other words, member states' commitment to a convention is a subject and inherent nature of the provisions of the convention is something else. Secondly, according to a customary rule when a legal rule is ratified, the rule is binding as long as it is valid and not repealed by next rule. Thus, when a large number of states ratify a treaty about the most basic and fundamental human subjects and observing it by governments is the basic condition for the exercise of fundamental, primary and legitimate rights of citizens, is the violation by some parties or their later political intentions a justification for rejecting the philosophy of formation of mentioned norms and a possibility to defy for other parties? In my opinion by no means.

From another point of view that is more challenging than the previous one, the most important reason for non-acceptance and lack of maximum implementation of international human rights law by some of the governments is ideological- moral differences between different nations. Based on this view, substantive differences in individual - social values between the West and some other countries, including Islamic countries make the hypothesis of the universality of international human rights unacceptable. "The underlying argument for this resentment from the Islamic states towards the universality of international human rights debate has predominantly been limited to a form of cultural relativism argument"(Moghaddam, 2012, p.13)Critical approach to modern human rights dimensions might be raised by different religious ideas as well as Post-Modernists critics of foundationalism and metanarratives. However, since ratification and implementation of international documents is naturally in the authority of governments, regardless of critical interpretations in the field of international relations, governments which adopt critical policies against international human rights conventions are generally divided into two groups. Islamic countries are the first category and another category includes fewer countries that, partly, the shadow of Marxist ideas still prevail over them.

The root of disputes about Islamic countries is the differences between the Islamic worldview and the liberal worldview, accordingly some of the provisions of the conventions on human rights assumed in basic contrary to Islamic laws. "In other words, the Islamic States argue that the UDHR does not fully correspond with Islamic traditions, particularly Shari'ah law values."(Moghaddam, ibid., p. 13) Sources of Islamic laws are different in the various Islamic sects. (Note14)But the 'Quran' and 'Sunnah' are two fundamental sources and common between the two main sects, 'Sunni' and 'Shia' and their branches. According to the Islamic shari'a, human beings are the same in terms of intrinsic qualities and Islamic commands passed in accordance with the instinct and the nature of humankind and in harmony with natural law.(Note15) Since the law of nature is constant and Islamic commandments have been revealed to the Prophet of Islam by the Lord (Allah), no one even Prophet himself is allowed to manipulate Islamic rules. However, other sources such as 'Ijma' (in Sunnism and Shiism) and 'Qiyas' (in Sunnism) are of other mechanisms for extracting the rules to meet the human needs in different periods and in the different subjects.

A number of Islamic human rights documents that they "are mostly known to represent the interest of conservative Muslims" (Saeden, 2010, p.20) codified in the recent decades due to the discrepancies between some of the Islamic rules and international human rights law which, naturally, their provisions indicate some important differences with international human rights conventions. But the most basic point of some fundamental differences between Islamic laws and the provisions of UNHRC is the issue of the source of law which, in turn, rooted in the different ontology of two schools. Unlike the humanist thinking reflected in the 'charter of human rights' in which the 'will of the people' is the source of law (Note 16) and 'social contract' are considered the guarantor of human social life, 'God's will' is considered as the source of law in Islam(Note 17) that is applied to the people through the Prophet. Therefore "Sharia is considered the total collection of theoretical laws that applies in an ideal Muslim community which has surrendered to the will of god."(Saeden, ibid, p.35) Thus, according to Islam, true law is just religious orders and the true sovereignty is for Islamic ummah. Islamic governance structure difference with other systems stems from this very fundamental difference 
and extends to other cases. For example, in discussing the meaning and scope of freedom, in contrast to liberal freedoms enshrined in human rights conventions which encompasses a wide range of freedom such as opinion, expression, religion, etc. and is only limited on the basis of laws of human societies, but in Islam the meaning of freedom is freedom versus other than Allah (Note 18) and its scope is limited to religious orders. (Note 19)

Another example is the discussion of individual equality. According to the provisions of the UNHRC all people enjoy equal rights regardless of religion, gender, etc. but the 'Cairo Declaration on Human Rights in Islam' [CDHRI] (1990) stressed on the equal human dignity, obligations and responsibilities of individuals (Note 20) and there are differences between Muslim and non-Muslim and men and women in Islamic laws. (Note 21)

Another example is the issue of penal code. While many punishments set forth in Islamic law, especially, 'Hudud' and 'Quesas' regarded as brutal punishments in terms of human rights conventions, from Islamic perspective the penalties are binding and of integral part of the mechanisms of Islamic laws as they are derived from the Quran explicit text. Besides, from a view the "severity of Islamic penal system is aimed at discouraging criminal behavior" (Okon, 2014, p.227) and from the Islamic point of view mentioned punishments have deterrent function and applying them is essential for social justice and personal salvation. The controversial topic of execution does fit in the same category. (Note 22)

Naturally, as a result of this fundamental difference ,the sources of law, is that the analysis of other issues such as minority rights, freedom to change religion, the age of majority, equality of opportunities, recognition of the rights of illegitimate children, etc. in the context of the Islamic countries laws and Human Rights Conventions has led to two diverse realms and many "Muslims therefore consider human rights to be a Western construct that must be met with an authentic Islamic response."(Berger, 2010, p. 9)

In the case of a minority of countries that their critical thinking is somehow Marxist-oriented, disputes rooted in the opposition of the communist thinking with the common sociopolitical structure which considered as capitalism components from the standpoint of Marxist. The basis of Marxist thought is 'Marx' and 'Engels's ideas which was later continued by others like 'Lenin'. For Marx, the fundamental realities are matter, production, distribution and also political economy and all other aspects of social life such as law are subsidiary and superstructural. Indeed, from Marxist perspective, law is the result of the class struggle. Also for "Marxism, social inequalities are reflections of the struggle between different social classes. Thus, according to Marx, eliminating class differences is the first step to ending inequality and attaining the full realization of all persons."(Engle, 2008, p.2) "Marx believed that a regular pattern of evolution controlled the human condition, which would then also lead to a more perfect society of classless individuals."(Zimmermann, 2009, p.93)

From Marxist view law is supplier of ruling class interests as well as other social mechanisms and also to "Marx, freedoms in liberal democracies are illusory, in that the freedoms advocated by liberal regimes are market values and are not centered on protecting basic human dignity... The principal Marxist critique of human rights is the fact that human rights are used to legitimate and justify the inegalitarian capitalist system... The Marxist critic of human rights asserts that the rights and freedoms of bourgeois democracies are purely formal and at most procedural and thus are illusions."(Engle,ibid.,p.1)"Civil society is for Marx the negation of the social essence of man. It is the sphere of unbridled individualism, of a pursuit of profit which leaves no stone unturned and of an overpowering egoism. According to Marx human rights only sanction and legitimize this egoism and are therefore the ideological expression of human alienation."(Herpen, 2012, p.10)

Regardless of more analysis about the quality and quantity of shortcomings raised by the governments criticizing liberal human rights system, the important point is that these governments ,critics, have never been able to be an efficient true model of a popular government capable of providing collective interests of people and their governance practices has always led to internal disputes and their international approach caused cross-border challenges. According to a chart showing the killing of citizens by government in different government systems between 1900 and 1987 we find that the number of "killed by own government in democratic system were 2 million, in authoritarian system 29 million and in totalitarian system 138 million. Included in the totalitarian/killed by own government cell are the 10 to 12 million human beings killed by the German national socialists in the period 1933-1945. Subtracting that number from 138 million, along with subtracting a few million killed by miscellaneous totalitarian regimes, means that over 110 million human beings were killed by the governments of nations inspired by left, primarily Marxist, socialism." (Hicks, 2004, p.148 \& 149) Currently, reports suggest multiple anti human rights approaches in communist countries territory. (Note 23)

One of the criticisms on Marxism is “... its subordination of freedom to ideology and the Communist Party's monopoly on power ... The valid critique is not the lack of 'freedom' but rather the presence of an all powerful party and an elite dictatorship which, rather than serving the people, aggrandized power for itself and ultimately 
restored capitalism to serve its own interests."(Engle, ibid., p.4) Marxists pushes back all the efforts of the international community by the capitalism label because Marx "considers all rights as the historical and social products the contents of which correspond with the level of the productive forces and relations of production."(Herpen, ibid., p.15)While the author believes that the issues relating to the production and whether its means owned by private individuals or not has nothing to do with the issues raised in the realm of human rights.Moreover, human rights is not born of capitalism which be flawed by Marxist rejection. In fact, the foundation of the issues discussed in the realm of human rights has nothing to do with any economic systems. This is apart from the philosophy of human rights that the contemporary international system to what extent has been able to overcome the class gap and expand social welfare. In other words "the issues of voluntarism and relativism go beyond the economic system."(Engle, ibid., p.3)In addition, it should be noted that international law ,presently, is a system within multiple political, legal and ideological systems and many socio-economic failures in contemporary history is in fact the result of non-compliance with international law regulations and as has been said "most factors of [economic] underdevelopment are derived from the political structure governing the developing countries, especially those "dualist states" that still have incredulous view on international law and see their seemingly national! Authoritarian reputation in conflict and confrontation with the organizations and rules of international law" (Akbari, 2016, p.98) Besides, based on the philosophy of the formation of contemporary international law institutions and given the humanitarian and undeniable role of human rights conventions in recent decades, this is an egregious mistake in Marxist discourse that law still considered as guarantor of the capitalists and the ruling class interests.

About the Islamic countries firstly, 'there is no single 'Islamic attitude' towards the legitimacy of international law and international agreements among the fifty-six nations that have adopted Islam as their official state religion, adopted Shari 'a as their legal system, or those that have Muslims as the majority or sizeable minority of their populations."(Govern, 2012, p.104) Secondly, "there are many Muslim scholars within or outside Islamic societies which have openly questioned, and challenged the principles of Shari'ah law."(Moghaddam, ibid., p.138) And the reaction of some Islamic governments against these scholars has been hostile. Also, reports suggest anti human rights regulations and behaviors in many of these countries. (Note 24)

On the codification and approval of Islamic human rights documents it is also noteworthy that by "doing so, they still pledge allegiance to human rights as a principle, especially in the form of international conventions, but at the same assert a separate identity for themselves. This position can be criticized for several reasons. First, the legal instruments that have been developed as Islamic human rights, pretend to be congruent with international standards of human rights, but they are not. Also, outsiders - Westerners, or non-Muslims if you will - are denied participation in debates or criticism of Islamic human rights documents for the mere reason that they lack (religious) ownership: by naming them Islamic human rights, they are appropriated for Islamic use only."(Berger, ibid., p.10)However, the UNHRC embrace wider range of schools and thoughts etc., and such "rights would include due process, freedom of expression, assembly and religion, and political participation in the process of government."(Show, ibid., p. 268)Moreover "when we return to the actual construct and mechanisms of human rights instruments, we are talking of conventions that are ratified by numerous states, including many Muslim countries."'(Berger, ibid., p. 10)

According to all of the above mentioned cases, the author believes the most important reason of non-compliance with UNHRC by critics is neither unwillingness of the citizens of these countries as a result of a fundamental conflict between their cultural values and human rights conventions, nor hallucination of assuming human rights demagogic because of its position in the contemporary socio-political structure, but political nature of the critics, which causes not only believe in legal dualism, but also, a number of these governments, grant no legitimacy for human rights and even all aspects of international law and know their mission opposing it.

\section{Conclusion}

Concluding treaties has been the means for creating mutual commitments and demands and a mechanism to guarantee human groups rights in different periods. In parallel to the development of human civilization and by the emergence of UN, which itself was the result of a universal agreement in the form of an international Charter, international treaties gained increasing importance and thus, after centuries of human endeavor in order to vindication of their fundamental rights, more opportunities were provided to human rights to be signed by national authorities as international collective agreements. Acknowledging the importance of international treaties in the strengthen the security of international community and the role of the $\mathrm{UN}$ to establish and maintain international consistency, the UN conventions should be recognized as the most important and most basic mechanisms to define, explain and identify human rights in contemporary era. Since the establishment of the UN, human rights conventions have managed to provide a comprehensive definition of multiple dimensions of human 
rights which compared to the past has been unprecedented and unparalleled. However, on the rest of the way some difficulties and barriers caused the objectives of the discussed conventions are not realized satisfactory in many parts of the world.

The aim of expressing the three difficulties derived from UNHRC is to convey this message that mentioned conventions are located in different realms of other treaties and contractual behavior in setting up these conventions is fundamentally wrong, because the provisions of the conventions, especially its central theme constitute an important part of international imperative rules. Therefore, accepting conditions in the text of the convention, such as reservation led to destabilize the human rights conventions status which the problems in question should be removed through some amendments and also be avoided in documents that will be approved in the future.

Supposing the effect of the treaties relative is due to lack of proper understanding of the essential difference between human rights conventions and other contractual treaties. Because of the fundamental issues brought in UNHRC and the imperative nature of their provisions, the privity of contract does not extend to these treaties. The author believes this misconception will be lost gradually through the growing development of international law.

But more basic challenge is the rejection of some UNHRC or some of their provisions by a number of governments under ideological or value reasons which has caused goals of UNHRC are not achieved desirably and human rights become the Achilles' heel of these governments. In the throes of this conflict, what can lead us toward unification of understanding and procedures relating to the human rights and resolving the conflict between critical minority view and liberal approach is that UNHRC provisions have no inconsistency in the original and general sense with moral systems (as it is presented by some Islamic governments) and also are not guarantor of a particular economic class's interests (as introduced by Marxist ideas).If Marxism concern is equality, the 'Universal Declaration of Human Rights' [UDHR] (1948) speaks about equal dignity and rights of all human beings, regardless of color, race, religion, etc.in very art.1 and 2, just as in some cases such as the right to privacy and the right to own property there is no contradiction between the Islamic countries approvals and UNHRC. Some differences like determining the age of majority are also solvable. But what should be done in other subject matters of the dispute the most important of which were mentioned earlier? If we believe that in the pluralistic world each group looks at the concept of human rights from its perspective, we will always witness serious conflicts and their negative consequences. Marxism had concerns such as equality, etc. within the enclosed framework of ideology (the ideology that led to failure in practice), but UNHRC regardless of unilateralism, declare the fundamental human rights. CDHRI with respect to human beings believes in the priority of principles of Islam and Muslims, whereas the UNHRC believe in equality of all human individuals along with respect to all of religions. Certainly, such an approach could be an important factor in reducing internal and international struggles in the current situation of the world.

According to this article, besides all these cases, dualism thinking is completely irrelevant to human rights. The aim of law in all societies should be providing order, security and social justice and consequently help improve human life and ultimately human prosperity. This concept, with no wane, extends to the international law and international community. Besides, international community prosperity means different societies prosperity and since the fundamental rights of a human being in a continent is not different with another human in another continent, the rules of international human rights normally be preferred over domestic law. Thus, the 'international responsibility of states' requires that we believe the supremacy of international rules and norms, because otherwise human rights will be subject to aggression for numerous reasons.

\section{Acknowledgments}

I would like to thank my dear Khatoon and Mr. Hamed Omidi for helpful cooperation

\section{References}

Akbari, B. (2016). The Role of International Law and Observance of Its Regulations on Countries Economic Development. Journal of Politics and Law, 9(7). https://doi.org/10.5539/jpl.v9n7p85

Allott, P. (1999). The Concept of International Law. European Journal of International Law (EJIL), 10, 31-50. https://doi.org/10.1093/ejil/10.1.31

Berger, M. (2010). Religion and Islam in Contemporay International Relations, Netherlands Instiute of International Relation, Clingendael Diplomacy Papers, No.27.

Bird, A. (2011). Third State Responsibility for Human Rights Violations. the European Journal of International Law, 21(4), 883-900. 
Brilmayer, L., \& Tesfalidet, I. Y. (2011). Third State Obligations and the Enforcement of International law. International law and Politics, 44(1), 1-53.

Buergenthal, T., Shelton, D. L., \& Stewart, D. P. (2009). International Human Rights in a Nutshell (4th ed.). GW Law Faculty Publications \& Other Works Retrieved from http://scholarship.law.gwu.edu/faculty_publications

Engle, E. (2008). Human Rights According to Marxism. Guild Practitioner, 65(249). Retrieved from https://papers.ssrn.com/sol3/papers.cfm?abstract_id=1021609

Fink, M. (2015). A 'Blind Spot' in the Frame work of International Responsibility? Third Party Responsibility for Human Rights Violations: The Case of Frontex, Pre-print. In T. Gammeltoft-Hansen, \& J. Vedsted-Hansen (Eds.), Human Rights and the Dark Side of Globalisation: Transnational Law Enforcement. Retrieved from http://papers.ssrn.com/so13/papers.cfm?abstract_id= 2591126

Fitzmaurice, M. (2002). Third Parties and the Law of Treaties, Max Planck Yearbook of United Nations Law, Vol. 6. 37-137. https://doi.org/10.1163/138946302775159433

Govern, K. H. (2012). Right to Peace or Human Rights per se in Islamic States. Ave Maria Law Review, 11(1), 103-123.

Hathaway, O. A. (2007). Why Do Countries Commit to Human Rights Treaties? Journal of Conflict Resolution, 51(4), 588-621. https://doi.org/10.1177/0022002707303046

Hathaway, O. A. (n.d.). Security and Human Rights. Retrieved from https://www.law.yale.edu/system/files/documents/pdf/Faculty/SecurityandHumanRights.pdf

Helfer, L. R. (2012). Terminating Treaties, 634-650. Retrieved from http://scholarship.law.duke.edu/cgi/viewcontent.cgi?article=5338\&context=faculty_scholarship

Herpen, M. H. V. (2012). Marx and Human Rights, Analysis of an Ambivalent Relationship, Cicero Foundation Great Debate Paper, No. 12.

Hicks, S. R. C. (2004). Explaining Postmodernism, Skepticism and Socialism from Rousseau to Foucault, Scholargy Publishing, USA.

Human Rights Committee. (1994). General Comment 24 (52), General comment on issues relating to reservations made upon ratifications or accession to the Covenant or the Optional Protocols thereto, or in relation to declarations under article 41 of the Covenant, U.N. Doc. CCPR/C/21/Rev.1/Add.6.

Kadkhodaei, A., \& Saed, N. (2011). Nezam e Beinolmelali e Hoghoogh e Bashar va Jang e Narm (International Human Rights System and Soft War), Rahbord-e farhang, No 16, 55-76, Iran. Retrieved from http://sccr.ir/UserFiles/Rahbord/16/3.pdf

Miles, T. J., \& Posner, E. A. (2008). Which States enter in to Treaties, and Why? Chicago, John M. Olin Law \& Economics Working Paper No. 420 (2nd series) Public Law and Legal Theory Working Paper No. 225.

Moghaddam, A. A. (2012). Towards International Islamic Human Rights: A comparative study of Islamic Law, Shari'ah, with universal human rights as defined in the International Bill of Human Rights, (a master's thesis submitted) University of Toronto. Canada.

Naldi, G. J., \& Magliveras, K.D. (2013) Human Rights and the Denunciation of Treaties and Withdrawal from International Organisations, XXXIII Polish Yearbook of international law, Polish Academy of Sciences Institute of Law Studies and the Committee on Legal Sciences, Warszawa.

Okon, E. E. (2014). Hudud Punishments in Islamic Criminal Law. European Scientific Journal, 10(14), 227-238.

Saedén, L. (2010). Alternative Islamic Human Rights. Lunds University Publications. Retrieved from http://lup.lub.lu.se/luur/download?func=downloadFile\&recordOId=1653579\&fileOId=1670218

Sangroula, Y. (2010). International Treaties: Features and Importance from International Law Perspective. Retrieved from http://papers.ssrn.com/so13/papers.cfm?abstract_id=2359978

Schrijver, N. J. (2006). The Future of the Charter of the United Nations, Max Planck Yearbook of United Nations Law, Vol. 10, 1-34. Netherlands. Retrieved from http://www.mpil.de/files/pdf1/mpunyb_01_schrijver_10.pdf

Show, M. N. (2008). International Law (6th ed.). Cambridge University Press. USA. https://doi.org/10.1017/CBO9780511841637 
Steinerte, E., \& Wallace, R. M. M. (2009). United Nations protection of human rights. University of London Press.

Swaine, E. T. (2006). Reserving. the Yale Journal of International Law, 31, 307-366.

UN. (2011). Guide to Practice on Reservations to Treaties, adopted by the International Law Commission (ILC) at its Sixty-third session. $\quad$ Retrieved http://legal.un.org/ilc/texts/instruments/english/drafts_articles/1_8_2011.pdf

Ziemele, I., \& Liede, L. (2013). Reservations to Human Rights Treaties: From Draft Guideline 3.1 .12 to Guideline 3.1.5.6. The European Journal of International Law, 24(4). https://doi.org/10.1093/ejil/cht068

Zimmermann, A. (2009). Marxism, law and evolution: Marxist law in both theory and practice. Journal of Creation, 23(3), 90-97.

\section{Notes}

Note 1. There is a dispute over this case, but the UN indication (Cf. http://www.un.org/en/events/humanri ghtsday/2008/history.shtml) and its General Secretary (Cf. http://www.un.org/sg/statements/index. asp?nid=6266) and British Museum (Cf. http://www.britishmuseum.org/about_us/news_and_press /press_releases/2012/cyrus_cylinder_travels_to_us.aspx) tend to confirm this view. Also, to know the supporter views see: Abtahi, H \& Boas, G. (2005). The Dynamics of International Criminal Justice: Essays in Honour of Sir Richard May, Martinus Nijhoff Publishers. I Avonius, L. \& Kingsbury, D. (2008); Human Rights in Asia: A Reassessment of the Asian Values Debate, Palgrave Macmillan, New york, US. I Carey, S. C. \& Gibney, M. \& Poe, S. C. (2010). The Politics of Human Rights: The Quest for Dignity, Cambridge University Press. ๆ Lauren, P.G. (2011). The Evolution of International Human Rights: Visions Seen, (3 ed.) University of Pennsylvania Press. ๆ Talbot, W.J. (2007). Which Rights Should Be Universal? (1 ed.) Oxford University Press.

And to know the oppositions views see: Briant, P. (2002). From Cyrus to Alexander: A History of the Persian Empire, translated by Peter T. Daniels, Winona Lake, Indiana, Eisenbrauns, US. ๆ Curtis, J. \& Tallis, N. (2005). Forgotten empire: the world of ancient Persia, with contributions by Beatrice Andre-Salvini, Berkeley: University of California Press. I Daniel, E. L. (2012). The History of Iran (The Greenwood Histories of the Modern Nations) 2nd ed. Greenwood Publishing Group. If Kuhrt, A. (1983). The Cyrus Cylinder and Achaemenid imperial policy, Journal for the Study of the Old Testament 25. I

Silverman, H. \& Ruggles, D. F. (2007). Cultural Heritage and Human Rights, Springer-Verlag New York.

And for more information about Cyrus Cylinder see: Finkel, I. (Editor) (2013) The Cyrus Cylinder, The King of Persia's Proclamation from Ancient Babylon, published by I. B. Tauris \& CO. LTD in association with the Iran Heritage Foundation. $\uparrow$ And see: http://cyruscylinder2013.com.

Note 2. e.g. The English Bill of Rights, Charters of freedom in United States, Declaration of the Rights of Man and of the Citizen in 1789, Declaration of Rights and Duties of Man and Citizen in 1795.

Note 3. See: Human Rights Watch (2016). World Report, events of 2015 \& Amnesty International (2016). Report 2015/16.

Note 4. It means those developing countries which have critical comments and approaches towards liberal aspects of international law, including international human rights laws.

Note 5. Art.20 the International Convention on the Elimination of All Forms of Racial Discrimination [ICERD] (1965); Art.28 the Convention on the Elimination of All Forms of Discrimination against Women [CEDAW] (1979); Art.28 Para2 the Convention against Torture and Other Cruel, Inhuman or Degrading Treatment or Punishment [CAT] (1984); Art.51 the Convention on the Rights of the Child [CRC] (1989); Art.46 the Convention on the Rights of Persons with Disabilities [CRPD] (2006);

Note 6. G.A. Res. 34/180 U.N. Doc. A/RES/34/180(Dec.18,1979) see http://www.un-documents.net/a34r $180 . \mathrm{htm}$

Note 7. For example: the reservations raised by Bangladesh, Libya and Malaysia.

Note 8. G.A. Res. 44/25 U.N. Doc. A/Res 44/25 (Nov.20,1989) see http://www.un.org/documents/ga/res/4 4/a44r025.htm

Note 9. For example the reservations raised by Kuwait, the Vatican, Iraq, Pakistan, Iran, Afghanistan, Qatar and Syria. 
Note 10. ICJ. (1951). Reservations to the Convention on the Prevention and Punishment of the Crime of Genocide, Advisory Opinion of 28 May.

Note 11. Art.21 ICERD (1965); Art.31 CAT (1984); Art.52 CRC (1989); Art 48 CRPD (2006); Art 12 the Optional Protocol to the International Covenant on Civil and Political Rights [ICCPR-OP1] (1966).

Note 12. Art.14 ICERD (1965); Art.22 Para1\& Art.28 Paral CAT (1984); Art.31 Para1 \& Art 32 the International Convention for the Protection of All Persons from Enforced Disappearance [CPED] (2006); Art.10 the Optional Protocol to the Convention on the Elimination of Discrimination against Women [OP-CEDAW] (1999).

Note 13. G.A. Res. 56/10 U.N. Doc. A/Res 56/10 (2001) see http://www.un.org/documents/ga/docs/56/a5 610.pdf

Note 14. See: Moghaddam, A. A. (2012). Towards International Islamic Human Rights: A comparative study of Islamic Law, Shari'ah, with universal human rights as defined in the International Bill of Human Rights, (a master's thesis submitted) University of Toronto. Canada. p: 25-36.

Note 15. See: the Quran: Surah 30:30.

Note 16. e.g. Art.21 the Universal Declaration of Human Rights [UDHR] (1948).

Note 17. See: the Quran: Surah 3:26 and Surah 23:88.

Note 18. See: Art.11 Para (a) \& Art.22 Para (a) the Cairo Declaration on Human Rights in Islam [CDHRI] (1990).

Note 19. Islamic rules divided into 5 general categories: Wajib, Mustahabb, Mobah, Makruh and Haram.

Note 20. Art.1 Para (a) CDHRI (1990).

Note 21. The introduction and Art.6 Para (a) CDHRI (1990).

Note 22. Art.2 Para (a) CDHRI (1990).

Note 23. See: Human Rights Watch (2016). World Report, events of 2015 I Amnesty International (2016). Report 2015/16 \ Reporters Without Borders (2016). World Press Freedom Index.

Note 24. Above (23)

\section{Copyrights}

Copyright for this article is retained by the author(s), with first publication rights granted to the journal.

This is an open-access article distributed under the terms and conditions of the Creative Commons Attribution license (http://creativecommons.org/licenses/by/4.0/). 